\title{
Potential risk in public parks: Investigation of the tick species (Acari: Ixodida) in Bursa metropolitan area, Turkey
}

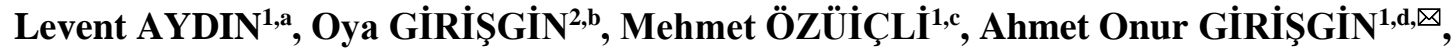 \\ Gözde COŞKUNSERÇE ${ }^{1, \mathrm{e}}$
}

\author{
${ }^{1}$ Bursa Uludağ University, Faculty of Veterinary Medicine, Department of Parasitology, Bursa; ${ }^{2}$ Bursa Uludağ University, \\ Vocational School of Karacabey, Bursa, Turkey. \\ aORCID: 0000-0002-2875-8003; ' 'ORCID: 0000-0001-9896-1093; ' $\mathrm{ORCID:} \mathrm{0000-0003-3415-2582;}$ \\ ${ }^{\mathrm{d} O R C I D: 0000-0002-0020-2708 ; ~}{ }^{\mathrm{e} O R C I D: 0000-0001-6365-3461 . ~}$
}

$\square$ Corresponding author: aogirisgin@uludag.edu.tr Received date: 12.12.2019 - Accepted date: 11.06.2020

\begin{abstract}
Ticks feed on a wide variety of mammals, birds, reptiles, and even amphibians. The majority of ticks choose specific animal species that are of no medical or veterinary importance for feeding, while others grasp a wide range of hosts, such as petbreeding animals or humans. They can also transmit many human and animal pathogens include viruses, bacteria, rickettsia and protozoa in Turkey. This study was carried out to detect the distribution of ticks in public parks in six districts (Osmangazi, Y1ldırım, Nilüfer, Gürsu, Kestel, Mudanya) of Bursa Metropolitan Municipality area (city centre) in Turkey, between May 2016 and May 2018. A total of 6186 ticks were collected with flagging or $\mathrm{CO}_{2}$ trapping method from the public parks. The collected ticks were kept in $70 \%$ alcohol and then were identified under a stereomicroscope. Seven hard or soft tick species according to five genera were identified as Rhipicephalus sanguineus, $R$. turanicus, Hyalomma marginatum, H. aegyptium, Dermacentor marginatus, Ixodes ricinus and Argas persicus. Among them, R. sanguineus was the most abundant (59.79\%) tick in the public parks. Ixodes ricinus increased significantly primarily in the forest areas. This is the first record of tick species in public parks in Turkey and these results may give us an acute insight into the prevalence of tick-borne infections in pets and humans.
\end{abstract}

Keywords: Bursa, public parks, tick species, Turkey.

\section{Parklardaki potansiyel tehlike: Türkiye’de Bursa Büyükşehir bölgesinde kene (Acari: Ixodida) türlerinin araştırılması}

Özet: Keneler beslenmelerini memeliler, kuşlar, sürüngenler ve hatta amfibiler gibi geniş bir konak çeşitliliğinden sağlamaktadır. Kenelerin büyük bir kısmı beslenmek için tıbbi veya veteriner önemi olmayan spesifik hayvan türlerini seçerken, bir kısmı da pet-yetiştiricilik hayvanları veya insan gibi çok çeşitli konaklara saldırmaktadır. Ayrıca Türkiye'de insan ve hayvanlarda gözlenen virus, bakteri, riketsiya ve protozoon gibi birçok etkenden kaynaklanan hastalıkları bulaştırmaktadır. Bu çalışma, Türkiye'de Bursa Büyükşehir Belediyesi sınırlarında, Mayıs 2016 ve Mayıs 2018 yılları arasında, altı ilçedeki (Osmangazi, Yıldırım, Nilüfer, Gürsu, Kestel, Mudanya) park ve piknik alanlarındaki kene türlerini belirlemek amacıyla yapılmıştır. Çarşaflama ve karbondioksit tuzaklama yöntemiyle toplam 6186 kene parklardan toplanmıştır. Toplanan keneler \%70'lik alkolde muhafaza edilmiş ve sonra stereo mikroskop ile teşhis edilmişlerdir. Beş cinse mensup yedi yumuşak veya sert kene türü; Rhipicephalus sanguineus, $R$. turanicus, Hyalomma marginatum, H. aegyptium, Dermacentor marginatus, Ixodes ricinus ve Argas persicus olarak belirlenmiştir. Bunların arasından en fazla $R$. sanguineus türüne $(\% 59,79)$ parklarda rastlanmıştır. Ağaçlık alanlarda Ixodes ricinus türü belirgin şekilde daha fazla bulunmaktadır. Çalışmamız, Türkiye'deki halka açık park ve piknik alanlarında bulunan kene türlerini belirlemeye yönelik ilk kayıtları içermektedir ve sonuçlarımız insan ve pet hayvanlarında gözlenen kene kaynaklı hastalıkların dağılımı yönünden bir ön bilgi verebilecektir.

Anahtar sözcükler: Bursa, kene türleri, parklar, Türkiye.

\section{Introduction}

Ticks are obligatory ectoparasites and may cause several serious infectious diseases either in humans or domestic/wild animals. Taxonomic studies on recent tick species indicated that the tick fauna of Turkey classified in two families, ten genera and 46 species infesting mammals, reptiles and birds $(4,5)$. There are several tick-borne diseases increasing in Turkey; Crimean Congo Haemorrhagic Fever Virus, Lyme, Ehrlichiosis, Anaplasmosis and Babesiosis are commonly seen in humans or domestic animals $(16,22,23)$. 
Bursa is located in the Marmara coast of North-East Turkey, between the Uludağ Mountain and the Marmara Sea $\left(40^{\circ} 11^{\prime} \mathrm{N} ; 29^{\circ} 04^{\prime} \mathrm{E}\right)$ and the altitude of Bursa is from 0 to $2500 \mathrm{~m}$ above sea level. The population of Bursa Province is about 3.8 million (2018 census) and more than half of the city's population (about 2.5 million) lives in urban areas of the city: Osmangazi, Yıldırım, Nilüfer, Gürsu, Kestel, Mudanya districts which consist the Bursa Metropolitan Municipality (Figure 1).

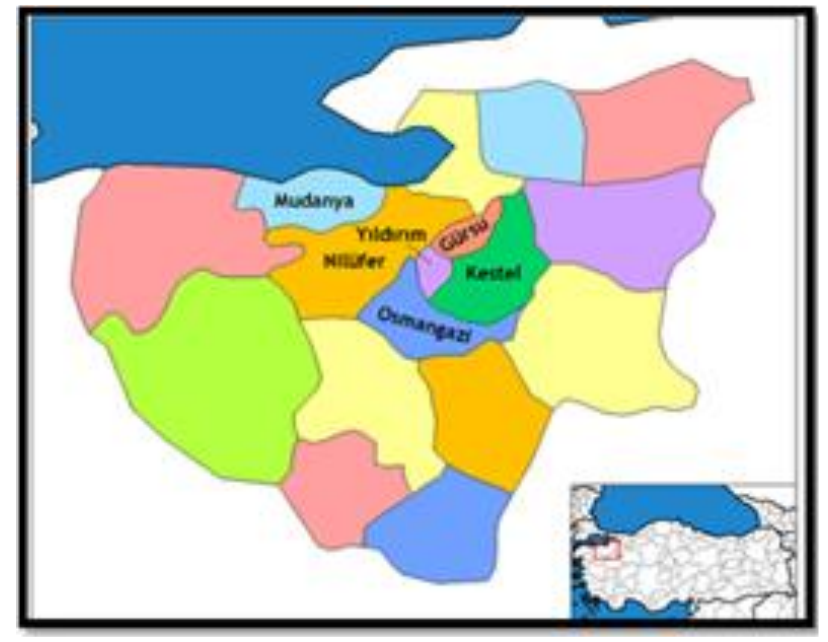

Figure 1. Map of the Bursa Metropolitan Municipality.

Bursa city is generally quite humid (average humidity of $73 \%$ ) due to its geographic location and the close proximity of the Marmara Sea. The total precipitation averages $706 \mathrm{~mm}$ per year, most of which recorded in December and the least in August. Bursa region is covered with mountains with natural forest (1). There are several public parks both in the city centre and rural areas where different species of bushes or trees are planted mixed. All of the parks investigated in this study can be used by the public as picnic areas at the same time.

Previous studies have shown that public parks in the city centre provide a basis for the habitat of ticks and related pathogens in European countries $(6,11,25,27,28$, 31, 33). Epidemiological studies on ticks in Turkey are mainly about the ones collected from domestic or wild animals and humans (3, 9, 12, 13, 15, 17, 18, 20, 24, 26). In this study, we aimed to investigate the tick species in the public parks where used by pets and people in the city centre and evaluate the risk status of ticks in Bursa Province.

\section{Material and Methods}

The study was carried out in six districts (Osmangazi, Yıldırım, Nilüfer, Gürsu, Kestel, Mudanya) of Bursa Metropolitan Municipality area (city centre) in Turkey, between March 2016 and May 2018, where tick specimens were collected with flagging for nidicolous ticks and with $\mathrm{CO}_{2}$ trapping for hunter species from 468 public parks or picnic areas. Tick sampling was carried out periodically at intervals of about a month in a year, totally two years (24 months). In every park, four parts of the area in different corners, surface of $300 \mathrm{~m}^{2}$ each were treated with flagging and sticking ticks were collected from the flag. Additionally, a shady area was selected near the trees for each park and a $\mathrm{CO}_{2}$ trap made by plastic parts was placed on the ground. The trap was controlled after four hours about the presence of insects and ticks were separated and collected. All the public parks examined in this study were at altitudes between 100 and $500 \mathrm{~m}$, which have a quite humid (73\% annual average) climate (1).

Ticks were collected from the flag or trap through a fine-tipped forceps and were kept in test tubes contains $70 \%$ ethanol, then were taken to the laboratory and placed in a refrigerator until diagnosis. Data of location, number of ticks and date of the collection were recorded. Species identification was performed under a stereomicroscope (Nikon SMZ-10) according to morphological characters by the keys of Aydın (2) and Walker et al. (34). Larvae and nymph ones were identified at the genus level, while adults were identified at the species level. Some individuals could not be identified because of their damaged body parts. Distribution and density frequency analysis of tick samples were determined via the formula determined by SPSS ${ }^{\circledR}$ programme (30).

\section{Results}

The study was carried out in six districts (Osmangazi, Yıldırım, Nilüfer, Gürsu, Kestel, Mudanya) of Bursa Metropolitan Municipality area (city centre) in Turkey, between May 2016 and May 2018. Seven hard or soft tick species belonging to five genera were identified as follows: Ixodes ricinus, Rhipicephalus sanguineus, $R$. turanicus, Hyalomma marginatum, $H$. aegyptium, Dermacentor marginatus and Argas persicus. Amongst them, $R$. sanguineus, $R$. turanicus and $I$. ricinus were common tick species in Bursa city and $R$. sanguineus $(59.79 \%)$ was the most abundant tick in the public parks (Table 1). Frequency of sampling of the I. ricinus was significantly higher in the forest and humid areas.

468 public parks or picnic areas were investigated for 24 months about ticks. Amongst districts, tick samples were mostly collected from Nilüfer, while fewest from Mudanya.

All the species of hunter ticks (Hyalomma marginatum and $H$. aegyptium) were collected from $\mathrm{CO}_{2}$ traps, while nidicolous ones were from flags. Argas persicus samples were collected from only one park in Nilüfer district where there are pigeon cages near the sampling areas. 
Table 1. Distribution of the ticks in each district parks.

\begin{tabular}{lcccccccc}
\hline & Osmangazi & Yıldırım & Nilüfer & Gürsu & Kestel & Mudanya & Total & \% \\
\hline Parks & 120 & 80 & 232 & 12 & 16 & 8 & 468 & \\
\hline R. sanguineus & 851 & 680 & 1871 & 113 & 126 & 57 & 3698 & 59.79 \\
R. turanicus & 147 & 51 & 195 & 14 & - & - & 425 & 6.88 \\
H. aegyptium & 37 & 26 & 122 & 9 & - & - & 194 & 3.13 \\
D. marginatus & 13 & 9 & 24 & - & 6 & - & 52 & 0.84 \\
H. marginatum & 18 & - & 26 & - & 12 & - & 56 & 0.91 \\
I. ricinus & 57 & 34 & 47 & - & - & - & 138 & 2.23 \\
A. persicus & 6 & - & - & - & - & - & 6 & 0.09 \\
Rhipicephalus spp. (nymph) & 42 & 73 & 186 & 121 & 81 & 48 & 551 & 8.91 \\
Rhipicephalus spp. (larvae) & 93 & 89 & 152 & 170 & 69 & 74 & 647 & 10.45 \\
Ixodes spp. (nymph) & 51 & 44 & 86 & - & 41 & - & 222 & 3.59 \\
Ixodes spp. (larvae) & 49 & 81 & 67 & - & - & - & 197 & 3.18 \\
\hline Total & 1364 & 1087 & 2776 & 427 & 353 & 179 & 6186 \\
\% & 22.05 & 17.57 & 44.88 & 6.90 & 5.71 & 2.89 &
\end{tabular}

Table 2. Seasonal mean activity of ticks collected from May 2016 to May 2018 in public parks of Bursa Province.

\begin{tabular}{|c|c|c|c|c|c|c|c|c|c|c|c|c|}
\hline Tick species & Jan. & Feb. & Mar. & Apr. & May. & Jun. & Jul. & Aug. & Sep. & Oct. & Nov. & Dec. \\
\hline$R$. sanguineus & & & + & + & + & + & + & + & + & + & & \\
\hline R. turanicus & & & & + & + & + & + & + & & & & \\
\hline H. aegyptium & & & & & + & + & + & + & + & & & \\
\hline D. marginatus & & & & & & & & + & + & + & + & \\
\hline H. marginatum & & & & + & + & + & + & & & & & \\
\hline I. ricinus & + & + & & & & & & & & + & + & + \\
\hline A. persicus & & & & & & & & & & + & + & \\
\hline Rhipicephalus spp. (larvae) & & + & + & + & + & + & + & & & & + & \\
\hline Rhipicephalus spp. (nymph) & & & + & + & + & + & + & + & + & & & \\
\hline Ixodes spp. (larvae) & & & & + & + & + & & & & & & \\
\hline Ixodes spp. (nymph) & & + & + & + & + & + & + & & & & & \\
\hline
\end{tabular}

Seasonal mean activities of all collected ticks were shown in Table 2. According to the data, adults of Rhipicephalus spp. and Hyalomma spp. were generally observed in spring and summer seasons, a peak from late May to early June. Adults of I. ricinus and D. marginatus were collected from autumn to early winter, the peak of late November. The undeveloped stages of Rhipicephalus and Ixodes were generally detected in spring and summer, and a small number of them were detected in early autumn. Argas persicus was identified only in a park in the spring where it contains pigeon cages inside (Table 2).

\section{Discussion and Conclusion}

In recent years, there has been a significant increase in tick-borne infections in Turkey. Especially Rickettsia, Lyme and Crimean Congo Haemorrhagic Fever (CCHF) may cause severe problems in humans or animals $(7,10$,
19, 32). There are considerable differences in tick epidemiology due to global climate change and unplanned urbanization and consequently, new tick-borne infections are expected $(14,21)$. Previous studies have shown that ticks are becoming increasingly as important vectors of pathogens in Europe's urban and peri-urban areas, which Ixodidae is the most common tick family encountered in Europe (6, 11, 25, 27, 28, 31, 33). In general, these types of studies were conducted for tick-borne diseases, not for tick species and were conducted in a limited area. Distinctly, there is no study about the tick species in the public parks of Turkey.

In a study of human ticks in Bursa Province of Turkey, a total of 19866 samples have been collected from human patients who applied to the hospitals suffering tick bites from the cities in the western part of Turkey between the years 2007 and 2011. Most of the ticks have been 
identified as Rhipicephalus spp. (72.98\%), Ixodes spp. (18.96\%) and Hyalomma spp. (7.18\%). Based on anamnesis, the majority of those patients have visited the parks, picnic or forestry areas where most of their ticks attached (81\%). Amongst them, Ixodes spp. species have been commonly found in highland and forestry areas of Bursa (29). However, other studies conducted on the human tick species in Turkey have resulted in the dominance of Hyalomma spp. mostly from the urbanised areas $(8,16,35)$. According to another study carried on ruminants in Bursa, 16 tick species belonging to 6 genera were detected in rural areas, and I. ricinus was the dominant species (3). Those results show that public parks/picnic areas have a significant source about ticks both for human and animals.

A high-intensity level of $R$. sanguineus detected in this survey is similar to the results gained from Selcuk et al. (29), which can be associated with the density of stray cats and dogs.

In conclusion, five genus and seven species of hard or soft ticks were identified in this study. Rhipicephalus sanguineus, $R$. turanicus and Ixodes ricinus were common tick species in Bursa city. While R. sanguineus (59.79\%) was the most abundant tick, $I$. ricinus increased significantly in the forest areas of the public parks. In general, tick-related epidemiological studies have been conducted on living hosts like humans or animals. However, this study contains the first record of tick species carried out in the living environment and from the field in Turkey. These results give us the distribution of tick species according to each district of Bursa Province and also their seasonal activities. This data can have potential value for the epidemiological studies of tickborne infections. Stray dogs and cats' population should be kept under control and antiparasitic drugs should be applied by municipalities and pet owners.

\section{Financial Support}

This research received no grant from any funding agency/sector.

\section{Ethical Statement}

This study does not present any ethical concerns.

\section{Conflict of Interest}

The authors declared that there is no conflict of interest.

\section{References}

1. Anonymus (2018): Turkish State Meteorological Service: Meteorological data in Bursa 1926-2017. Available at https://www.mgm.gov.tr/veridegerlendirme/il-ve-ilceleristatistik.aspx?m=BURSA. (Accessed December 28, 2018).

2. Aydın L (1994): Distribution and species of tick on ruminants in the South Marmara region. MSc thesis. University of Uludağ, Bursa, Turkey.

3. Aydın L (2000): Distribution and species of ticks on ruminants in the South Marmara Region. Acta Parasitol Turc, 24, 194-200.

4. Aydin L, Bakirci S (2007): Geographical distribution of ticks in Turkey. Parasitol Res, 101, 163-166.

5. Bursali A, Keskin A, Tekin S (2012): A review of the ticks (Acari: Ixodida) of Turkey: Species diversity, hosts and geographical distribution. Exp Appl Acarol, 57, 91-104.

6. Corrain R, Drigo M, Fenati M, et al (2012): Study on ticks and tick-borne zoonoses in public parks in Italy. Zoonoses Public Health, 59, 468-476.

7. Çetinkaya H, Matur E, Akyazi I, et al (2016): Serological and molecular investigation of Ehrlichia spp. and Anaplasma spp. in tick and blood of dogs, at Thrace Region of Turkey. Ticks Tick-Borne Dis, 7, 706-714.

8. Gargılı A, Kar S, Yılmazer N, et al (2010): Evaluation of ticks biting humans in Thrace Province, Turkey. Kafkas Univ Vet Fak Derg, 16, S141-S146.

9. Göksu K (1967): Tick infestations and Babesidae (Sporazoa: Piroplasmida) infections of cattle in Blacksea Provinces. Ankara Univ Vet Fak Derg, 1, 46-57.

10. Göral G, Kılıçturgay K, Aydın L (1997): Antibody prevalence against Borrelia burgdorferi in some villages in Province of Bilecik. Tr J Med Sci, 27, 51-53.

11. Hansford KM, Fonville M, Gillingham EL, et al (2017): Ticks and Borrelia in urban and peri-urban greenspace habitats in a city in southern England. Ticks Tick-Borne Dis, 8, 353-361.

12. Hoffman G, Hörchner F, Schein E, et al (1971): Saisonales Auftreten von Zecken und Piroplasmen bei Haustieren in den asiatischen Provinzen der Türkei. Berl Münch Tierarztl, 94, 152-156.

13. Hoogstraal H (1959): Biological observations on certain Turkish Haemaphysalis ticks (Ixodoidea, Ixodidae). J Parasitol, 45, 227-232.

14. Jongejan F, Uilenberg G (2004): The global importance of ticks. Parasitol, 129, S3-S14.

15. Karaer Z, Yukarı BA, Aydin L (1997): Türkiye Keneleri ve Vektörlükleri. 363-458. In: MA Özcel, N Daldal (Eds), Parazitoloji'de Artropod Hastalıkları ve Vektörler. Ege Üniversitesi Basımevi, İzmir.

16. Karaer Z, Guven E, Nalbantoglu S, et al (2011): Ticks on humans in Ankara, Turkey. Exp Appl Acarol, 54, 85-91.

17. Kurtpınar H (1954): Türkiye Keneleri. Güven Matbaası, Ankara.

18. Merdivenci A (1969): Türkiye Keneleri Üzerine Araştırmalar. Kutulmuş Matbaası, İstanbul.

19. Mertens M, Schmidt K, Ozkul A, et al (2013): The impact of Crimean-Congo hemorrhagic fever virus on public health. Antiviral Res, 98, 248-260.

20. Nemenz H (1967): Zecken aus der Türkei (Acari, Ixodidea). Zool Anz, 178, 191-195.

21. Orkun Ö, Karaer Z, Çakmak A, et al (2014): Spotted fever group Rickettsiae in ticks, Turkey. Ticks Tick-Borne Dis, 5, 213-218. 
22. Orkun Ö, Karaer Z, Çakmak A, et al (2014): Identification of tick-borne pathogens in ticks feeding on humans in Turkey. PLoS Negl Trop Dis, 8, e3067.

23. Orkun Ö, Karaer Z, Çakmak A, et al (2017): CrimeanCongo hemorrhagic fever virus in ticks in Turkey: A broad range tick surveillance study. Infect Genet Evol, 52, 59-66.

24. Oytun HŞ (1947): Keneler, Zararları ve Savaş Çareleri. YZE Basımevi, Ankara.

25. Rogovskyy AS, Nebogatkin IV, Scoles GA (2017): Ixodid ticks in the megapolis of Kyiv, Ukraine. Ticks Tick-Borne Dis, 8, 99-102.

26. Sayın F, Dumanlı N (1982): Epizootiologic investigations on tick (Ixodoidea) species of domestic animals in Elazlğ Province. Ankara Univ Vet Fak Derg, 29, 344-362.

27. Schorn S, Pfister K, Reulen H, et al (2011): Prevalence of Anaplasma phagocytophilum in Ixodes ricinus in Bavarian public parks, Germany. Ticks Tick-Borne Dis, 2, 196-203.

28. Schorn S, Pfister K, Reulen H, et al (2011): Occurrence of Babesia spp., Rikettsia spp. and Bartonella spp. in Ixodes ricinus in Bavarian public parks, Germany. Parasit Vectors, 4, 135.
29. Selcuk Ö, Aydın L, Girişgin AO, et al (2015): Long term investigations on tick infestations of human. Kafkas Univ Vet Fak Derg, 21, 795-798.

30. SPSS $^{\circledR}$ for Windows (2018): Rel. 17.0.0. IBM Statistics 23, Chicago: SPSS Inc.

31. Tretyakov KA, Medvedev SG, Apanaskevich MA (2012): Ixodid tick in St. Petersburg: A possible a threat to public health. Est J Ecol, 61, 215-224.

32. Tuncer D, Mutlu G, Karaer Z, et al (2004): Seasonal occurrence of ticks on goats and Borrelia burgdorferi influence in Ixodes ricinus in Antalya region. Türkiye Parazitol Derg, 28, 158-160.

33. Uspensky I (2014): Tick pest and vectors (Acari: Ixodidea) in European towns: introduction, persistence and management. Ticks Tick-Borne Dis, 5, 41-47.

34. Walker AR, Bouattour A, Camicas JL (2003): Ticks of Domestic Animals in Africa: A Guide to Identification of Species. Bioscience Reports, Edinburgh, Scotland.

35. Yücesan BÇ, Babür C, Sezen F, et al (2019): Ankara'da insana tutunan kene türleri: Tür çeşitliliği, konak özellikleri ve coğrafi dă̆llımı. Turk Hij Den Biyol Derg, 76, 3-14. 